\title{
Platebaikalia - a new monoraphid diatom genus from ancient Lake Baikal with comments on the genus Platessa
}

\author{
Maxim S. KulikovskiY ${ }^{1 *}$, Anton M. Glushchenko ${ }^{1}$, Sergei I. Genkal ${ }^{2}$, Irina V. \\ KuZnetsova $^{1} \&$ John P. KocioleK ${ }^{3,4}$
}

\author{
${ }^{\prime}$ K.A. Timiryazev Institute of Plant Physiology RAS, IPP RAS, 35 Botanicheskaya St., Moscow, 127276, Russia, \\ *Corresponding authore-mail: max-kulikovsky@yandex.ru \\ ${ }^{2}$ Papanin Institute for Biology of Inland Waters, Russian Academy of Sciences, 152742 Yaroslavl, Nekouz, \\ Borok, Russia \\ ${ }^{3}$ Museum of Natural History and ${ }^{4}$ Department of Ecology and Evolutionary Biology University of Colorado, \\ Boulder, Colorado, 80309 USA
}

\begin{abstract}
A new monoraphid diatom genus, Platebaikalia gen. nov., was described based on a detailed morphological investigation using light and scanning electron microscopy. Previously Platessa elegans Kulikovskiy et Lange-Bertalot was described from ancient Lake Baikal, and this species serves as the generitype for the newlydescribed genus. Platebaikalia elegans is a rare taxon found in the deeper parts of Lake Baikal. Platebaikalia elegans is characterized by having multiseriate striae on the raphe valves with biseriate striae on the rapheless valves, though in some specimens a short third row of areolae may be present in some striae. Morphology of striae is helpful to distinguish the genus Platebaikalia from Platessa and other monoraphid genera. Other morphological features that differentiate our new genus from other monoraphid taxa are discussed. We review the morphological data on Platessa species, and based on these data can recognize eight groups of taxa in the genus. Our analysis shows that Platessa as currently circumscribed may contain groups of species that are quite different from one another morphologically, and possibly includes taxa that could be recognized as different at the genus level. A few new combinations are suggested when taxa from the genus Platessa transferred to genera Psammothidium and Planothidium. Some problems of taxonomy of monoraphid taxa are discussed and we believe that taxonomy of this group of diatoms is in need of special attention in future.
\end{abstract}

Key words: diatoms, Platebaikalia, Platessa, new genus, morphology, monoraphid, taxonomy, ancient lakes, Baikal

\section{INTRODUCTION}

Lake Baikal includes about 1500 species of diatoms (JASNITSKY 1936, 1952; SKVORTZOW \& MEYER 1928; SkVORTZOW 1937; SKABICHEVSKIY 1936, 1952, 1975, 1984, 1985, 1987; KuLIKOvSKIY papers). A comprehensive revision of species and genera present in Lake Baikal was given in two monographs by KULIKovsKIY et al. $(2012,2015)$. Their work showed the unique nature of the flora of monoraphid, biraphid and araphid diatoms from this ancient lake system. Monoraphid diatoms in Lake Baikal include a large number of species from previously described genera like Eucocconeis P.T. Cleve ex F. Meister, Karayevia Round \& Bukhtiyarova (1998), Nupela Vyverman et Compère, Planothidium Round et Bukhtiyarova, Platessa Lange-Bertalot and Achnanthidium Kützing (SKvortzow \& MeYer 1928; Skvortzow 1937; KuLIKOvskiY et al. 2009, 2011, 2012, 2015). Three new monoraphid genera were described from Lake Baikal including Skabitschewskia Kulikovskiy et Lange-Bertalot, Trifonovia Kulikovskiy et LangeBertalot and Gliwiczia Kulikovskiy, Lange-Bertalot et Witkowski. During the revision of monoraphid diatoms from Lake Baikal about 55 new species were described (KulikovskiY et al. 2009, 2011, 2012, 2013, 2015). Genera such as Karayevia, Skabitschewskia, Nupela and Planothidium have the greatest diversity of species among the monoraphid diatoms (KuLIKovsKIY et al. 2015). Five species were described from the genus Platessa (Kulikovskiy et al. 2015).

Lange-Bertalot (Krammer \& LANGe-Bertalot 2004) proposed the monoraphid genus Platessa LangeBertalot on the basis of morphological features such as small, elliptic, flat valves with morphologically similar raphe and rapheless valves, the presence of a stauros-like structure on the rapheless valves, areolae of both valves occluded by hymenes, and predominantly biseriate striae in both valves. Krammer \& LANGE-BERTALOT 
(2004) transferred to the genus taxa formerly assigned to Cocconeis Ehrenberg and Achnanthes Bory sensu lato, and the genus originally included 10 taxa (Table). Later, new species were described or transferred to this genus, including from North America, Europe, and Asia. Currently, the genus Platessa includes about 28 species known (KocioleK et al. 2019).

Some of species from the genus Platessa in Lake Baikal do not share all of the morphological features typical of the generitype, Platessa bavarica Lange-Bertalot et Hofmann (Krammer \& LANGE-Bertalot 2004). One of these species from Lake Baikal is Platessa elegans Kulikovskiy et Lange-Bertalot (KuLIKovskiY et al. 2015). This species is very rare in samples from Lake Baikal and known from samples from the deeper parts of the lake (KuLIKovskiY et al. 2015). This species was placed into the genus Platessa provisionally with remarks that its placement in this genus needed to be confirmed or refuted in the future. The authors called for a more comprehensive morphological investigation of raphe and rapheless valves of this taxon (KULIKOVSKIY et al. 2015).

The aim of this publication is to provide additional morphological evidence of the fine structure of a very rare monoraphid diatom, Platessa elegans, and based on the results of this study to describe the genus Platebaikalia gen. nov. to recognize its differences relative to Platessa.

\section{Materials ANd Methods}

For this study we used samples from Lake Baikal collected by A.P. Skabitschewsky on 20 July 1965 from bottom deposits surrounding Ushkan'i Islands, obtained from the collection of Galina Khursevich (Minsk, Belarus). For a complete list of samples, please consult KuLIKovsKiY et al. (2012). The genus proposed here is based on species is described from the sample number SZCZ 15645 - substratum: sand, Ushkan'i Islands 42 $\mathrm{m}$ depth, off Bolshoi Ushkan'i Island.

The samples were boiled in concentrated hydrogen peroxide $(\approx 37 \%$ ) to dissolve organic matter. The samples were then washed with deionized water four times at $12 \mathrm{~h}$ intervals. After decanting and rinsing with up to $100 \mathrm{ml}$ of deionized water, the suspension was spread onto coverslips and left to dry at room temperature. Permanent diatom slides were mounted in Naphrax ${ }^{\circledR}$. Light microscopic (LM) observations were performed with a Zeiss Scope A1 microscope equipped with an oil immersion objective (100×, n.a. 1.4, differential interference contrast [DIC]) and Zeiss AxioCam ERc 5s camera. For scanning electron microscopy (SEM), parts of the suspensions were fixed on aluminum stubs after air-drying. The stubs were sputter coated with $50 \mathrm{~nm}$ of gold. Valve ultrastructure was examined by means of a JSM-6510LV scanning electron microscope (Institute for Biology of Inland Waters RAS, Borok, Russia).

\section{RESULTS}

Platebaikalia Kulikovskiy, Glushchenko, Genkal et Kociolek gen. nov. (Figs 1-33)

Type species: Platebaikalia elegans (Kulikovskiy et LangeBertalot) Kulikovskiy, Glushchenko, Genkal et Kociolek comb. nov.

\section{Description}

LM (Figs 1-4), raphe valves: Valves elliptical with more or less rounded ends. Length 16-28 $\mu \mathrm{m}$, breadth 9-11 $\mu \mathrm{m}$. Axial area narrow, becoming expending slightly to form an irregularly-shaped central area. Raphe filiform, external proximal ends distinctly dilated, straight. Striae costa-like, without distinct areolae, some tapering slightly towards the axial area, radiate, 6-8 / $10 \mu \mathrm{m}$, interstriae narrow.

LM (Figs 5-13), rapheless valves: Axial area lanceolate, narrow at poles. Length $12-32.5 \mu \mathrm{m}$, breadth $8-12$ $\mu \mathrm{m}$. Central area not differentiated, though one stria in the center may be shorter than the others. Striae wide, distinctly multiseriate, tapering towards the axial area, radiate, 7-9 / $10 \mu \mathrm{m}$, with narrow interstriae.

SEM (Figs 14-23), raphe valves: Valves with straight raphe, bordered with a narrow rim at the face mantle junction. Raphe with dilated external proximal raphe end and slightly dilated external distal raphe ends. Striae multiseriate, comprised of up to 7 rows near the margin and 1-4 rows bordering the axial area. Areolae round, unoccluded externally. Internally, the central sternum and narrow interstriae are robust and project inwardly. The proximal raphe ends terminate on the central nodule and are turned barely in opposite directions. Distal raphe ends terminate as helictoglossae, before the apices of the valves. Occlusions are not evident.

SEM (Figs 24-33), rapheless valves: Externally, the central sternum is evident, and narrowly lanceolate. Striae area comprised of multiseriate rows, 3-4 near the margins, and ends 1-2 rows near the ends along the sternum. The margin is rimmed by short siliceous nodules, thicker at the interstriae. On the mantle there are groups of areolae in units of 3 areolae that bear siliceous flaps. Internally, the morphology is dominated by the inwardly-projecting wide central sternum and thickened interstriae. Areolae are covered by thickened siliceous membranes, with opening being narrow to irregularly wide.

Etymology: Combining epithet refers to the similarity with the genus Platessa and type locality (Lake Baikal).

\section{Discussion}

Platebaikalia gen. nov. is a new genus that very easily be distinguish from other known freshwater monoraphid diatom taxa included previously in the catch-all genus Achnanthes Bory sensu lato. These are Platessa, Achnanthidium, Skabitschewskia, Planothidium, Crenotia, Eucocconeis, Gliwiczia, Lemnicola, Psammothidium, Trifonovia. Comparison of these genera on the basis of morphological data is given in Supplementary table. We did not include Karayevia in Supplementary table because the genus is so different morphologically from the others in our comparison. Karayevia is characterized by striae with one or just a few large areolae. This genus is independent from other monoraphid genera phylogenetically and belongs to the family Stauroneidaceae 

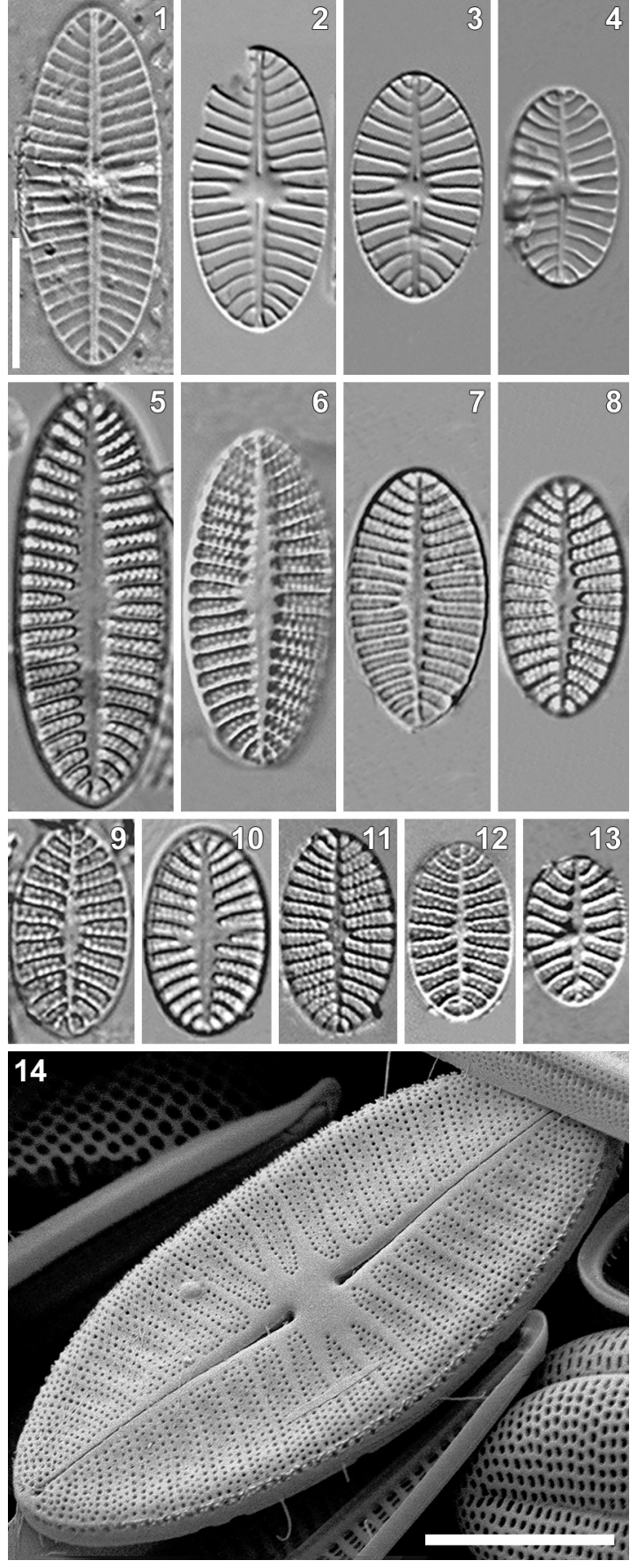

Figs 1-14. Platebaikalia elegans comb. nov. LM, DIC (Figs 1-13), SEM, raphe valve, external views (Fig. 14). Scale bars $10 \mu \mathrm{m}(1-$ 13), $6 \mu \mathrm{m}(14)$

D.G. Mann together with two other marine monoraphid genera, Madinithidium and Schizostauron (DAVIDOVICH et al. 2017; KulikovskiY et al. 2016, 2019). Freshwater genera such as Achnanthidium, Lemnicola, Eucocconeis, Rossithidium, Psammothidium and Planothidium have also been studied using molecular methods (KULIKOVSKIY et al. 2016, 2019; NAKOv et al. 2019). They are part of a monophyletic, independent branch in a phylogenetic tree that can be recognized as the family Achnanthidiaceae D.G. Mann (Cox 2015; KuLIKovskiY et al. 2016).
Platebaikalia gen. nov. is distinguished from other monoraphid genera on the basis of striation on both raphe and rapheless valves. Platebaikalia gen. nov. is characterized by the presence of multiseriate striae on raphe valves and biseriate striae with tendency to multiseriate (with three row of areolae) on rapheless valves. Planothidium shares the same morphological feature, but in Planothidium multiseriate striae are known on both the raphe and rapheless valves (Round \& BukHtiYARova 1996; VAN De ViJver et al. 2013). Moreover, species of Planothidium share multiseriate striae that include up to 5 rows of areolae on both valves (Round \& Bukhtiyarova 1996; VAN De Vijver et al. 2013). Platebaikalia gen. nov. is characterized by having multiseriate striae with up to seven rows of areolae on raphe valve (see Fig. 21). Other genera are characterized by uniseriate or biseriate striae (see Supplementary table). In many genera, the structure of the striae is the same in raphe and rapheless valves. Platessa, Crenotia, and Lemnicola are characterized by having biseriate striae on both valves, while Achnathidium, Eucocconeis, Gliwiczia, Psammothidium and Trifonovia are characterized by having uniseriate striae only (LANGE-BERTALOT \& RUPPEL 1980; LANGe-Bertalot \& Krammer 1989; Round et al. 1990; BuKHTIYAROVA \& ROUND 1996; Round \& BASSON 1997; Krammer \& Lange-Bertalot 2004; Monnier et al. 2007; PotaPova \& Hamilton 2007; ENACHE \& Potapova 2012; WoJtal 2013; KULIKOVSKIY et al. 2013, 2015; Novais et al. 2015; RoMero 2016; SHi et al. 2018). Skabitschewskia is the only monoraphid genus that has raphe valves with uniseriate striae and rapheless valves with biseriate striae (KULIKOVSKIY et al. 2015).

In many genera, areolae are covered by hymenes as pore occlusions (see Supplementary table). However, hymenes were not detected in Skabitschewskia and Gliwiczia (KuLIKovskiy et al. 2013, 2015). Our investigation of pore occlusions in Platebaikalia gen. nov. using SEM did not allow us to observe pore occlusion with hymenes. Hymenes are characterized by a slim silica plate with many tiny pores that are differently shaped (MANN 1981). However, in Platebaikalia gen. nov. areolae are covered internally by very strong convex membranes on the rapheless valves (see figs 34,35 ) and raphe valves (see figs 28, 29). Moreover, in raphe valves the areolae are covered additionally by a silica cover internally that cover multiseriate stria between prominent strong rib-like multistriae (see Fig. 28). In Gliwiczia pore occlusions are characterized additionally by the presence of a pair of foramina lips below the silica membranes (KuLIKovskiY et al. 2015).

Morphology of the raphe system, mainly the distal and proximal raphe endings, is another morphological feature that makes it possible to differentiate between genera of monoraphid diatoms (see Supplementary table). Monoraphid genera differ on the basis of distal raphe ends that can be on valve face only or extending onto the valve mantle (see Supplementary table). Another important feature is direction of curvature of distal raphe ends, either 
in the same or opposite directions. Internally, distal raphe ends in many monoraphid genera terminate as helictoglossae, but the helictoglossae can be turned to the same or different directions or to be straight. Platebaikalia gen. nov. is characterized by straight external distal raphe ends on valve face, a feature that the new genus shares with Platessa, Achnathidium, Gliwiczia and Psammothidium. Internally, distal raphe ends of Platebaikalia gen. nov. are straight and that differentiates our new genus from others such as Platessa, Achnanthidium, Skabitschewskia, Planothidium, Eucocconeis, Gliwiczia and Lemnicola which have helictoglossae that are curved in opposite directions (see Supplementary table).

External proximal raphe ends differ between different genera in terms of shape and direction of curvature, either to the same or different sides. Platebaikalia gen. nov. is characterized by having straight external proximal raphe ends, similar to the condition found in genera Platessa, Achnathidium, Skabitschewskia, Eucocconeis, Gliwiczia and Psammothidium. Internally, Platebaikalia gen. nov. has proximal raphe ends curved to different sides, similar to the situation almost all freshwater monoraphid genera (see Supplementary table).

Other morphological features such as the structure of the axial area and central area are also constant features
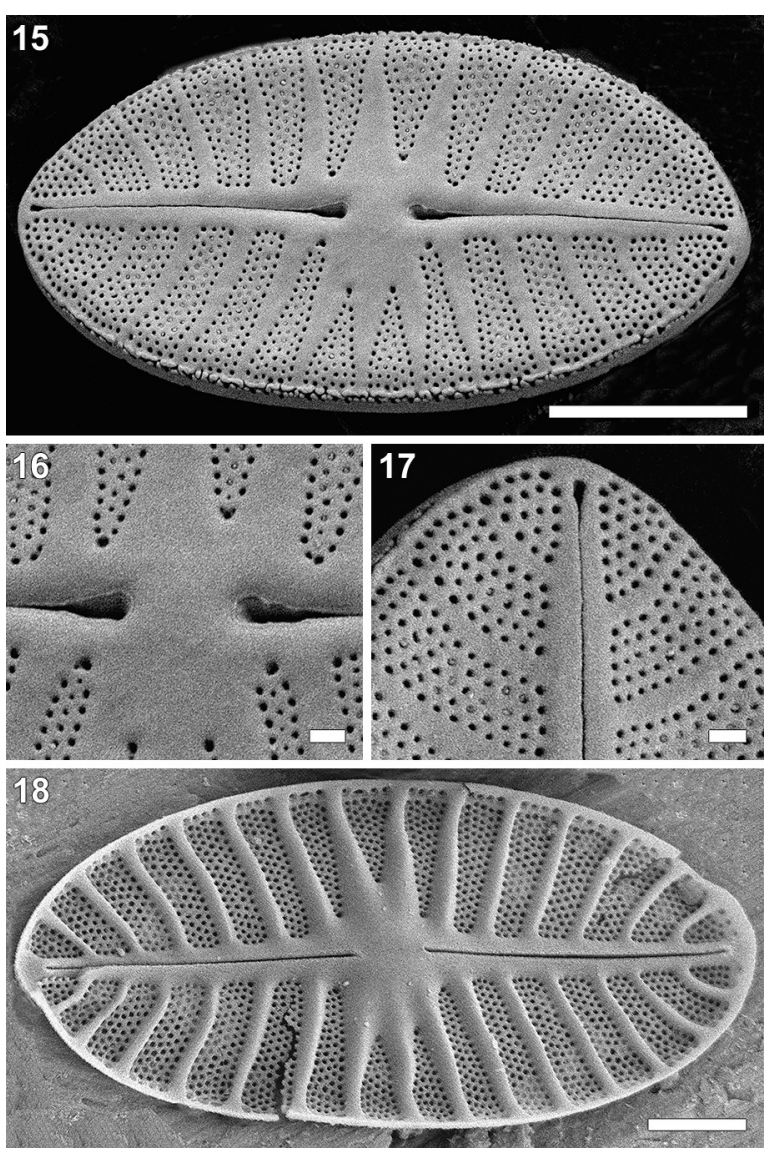

Figs 15-18. Platebaikalia elegans comb. nov. SEM, raphe valves: (15) external view of the whole valve; (16) external view of the central area; (17) external view of the valve end; (18) internal view of the whole valve. Scale bars $5 \mu \mathrm{m}$ (15), $3 \mu \mathrm{m}$ (18), $0.5 \mu \mathrm{m}(16,17)$. in the monoraphid genera of the Achnanthidiaceae, and can be used to delimit genera. Platebaikalia gen. nov. has very broad, multiseriate striae and narrow interstriae that differentiate this genus from Platessa. In Platessa, biserite striae are narrow and alternate with interstriae. In Platessa every biseriate stria terminates in one marginal poroid (ROMERo 2016). These poroids are organized as a tiny marginal row of poroids (KRAMMER \& LANGE-Bertalot 2004; Romero 2016). In contrast to the situation in Platessa, in Platebaikalia gen. nov. every multiseriate stria corresponds to three or four poroids that are separated by very prominent interstriae internally. Externally, these poroids are organized in a continuous row of tiny poroids on valve mantle.

Platebaikalia gen. nov. can be easily distinguished from all other known freshwater monoraphid genera by the presence of multiseriate striae on raphe and rapheless valves (the rapheless valves are biseriate with a tendency to multiseriate striae). However, the structure of the multiseriate striae are not the same on the two valves of a frustule. On raphe valves, the striae include up to seven rows of areolae but in rapheless valves the striae have only three rows of areolae near mantle and become biseriate near axial area. Only in Planothidium do we see a similar structure, where there are multiseriate striae that are the same in raphe and raphless valves, with no more than five rows of areolae. Presence of cavum and sinus in Planothidium (JAHN et al. 2017) distinguishes
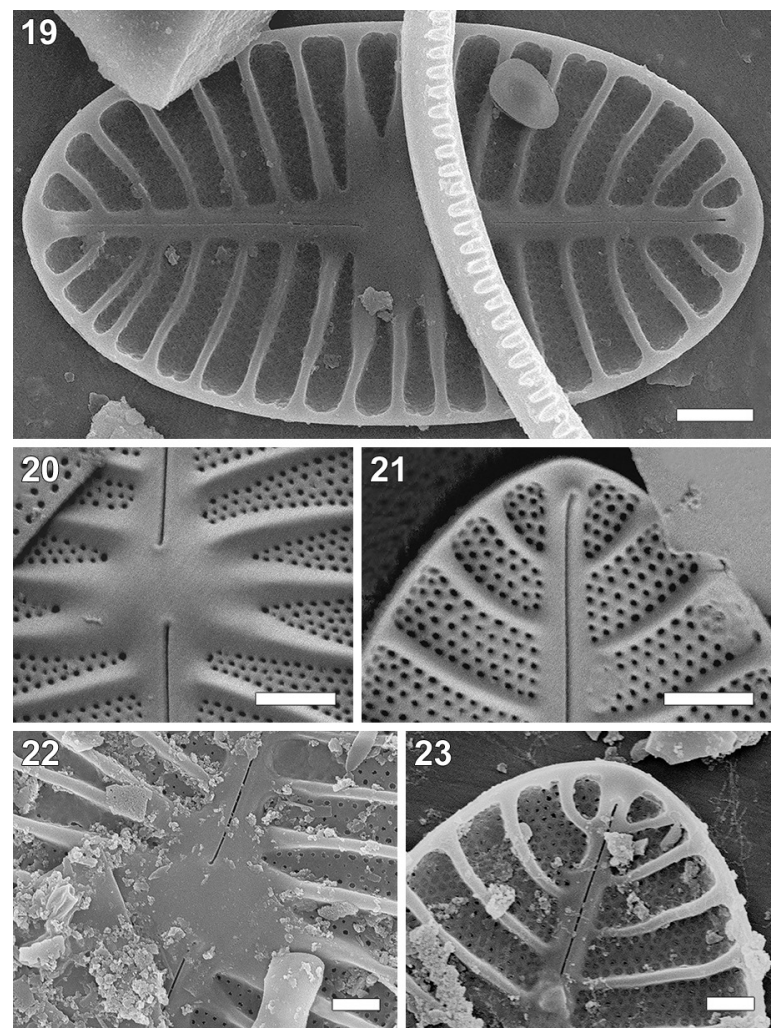

Figs 19-23. Platebaikalia elegans comb. nov. SEM, raphe valves, internal views: (19) whole valve; $(20,22)$ view of the central area; $(21,23)$ view of the valve end. Scale bars $2 \mu \mathrm{m}$ (19), $1.5 \mu \mathrm{m}(20$, 21), $1 \mu \mathrm{m}(22,23)$. 

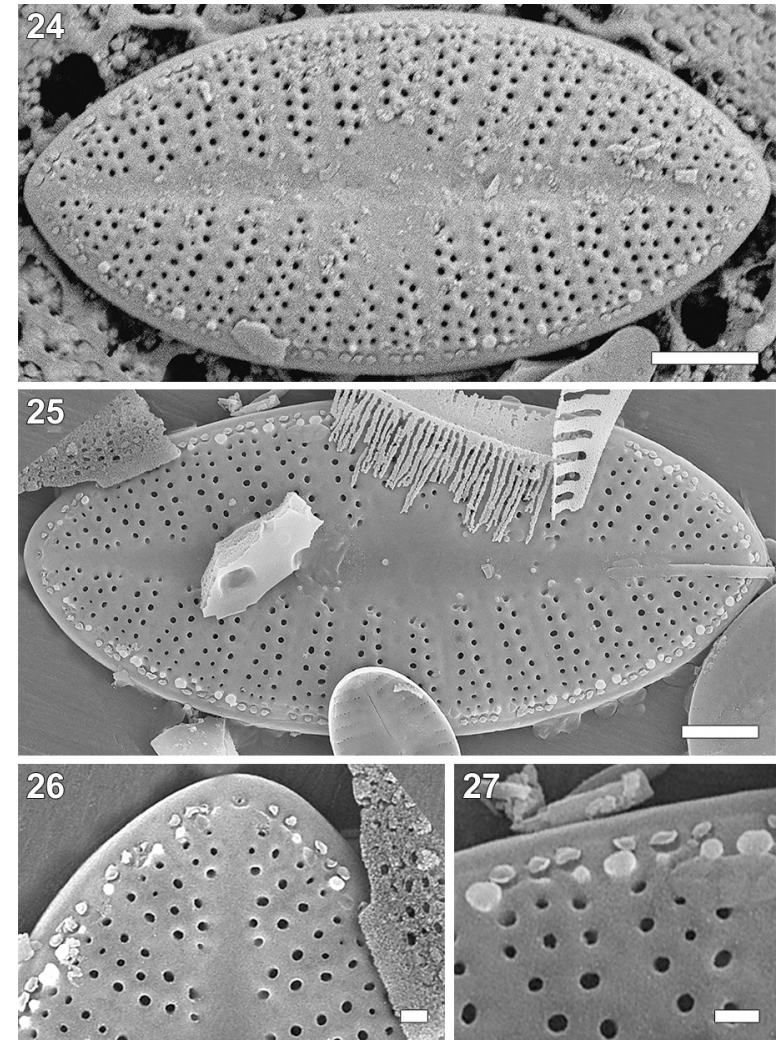

Figs 24-27. Platebaikalia elegans comb. nov. SEM, rapheless valves, external views: $(24,25)$ whole valve. external view of the central area; (26) view of the valve end; (27) view of the valve margin. Scale bars $3 \mu \mathrm{m}$ (24), $2.5 \mu \mathrm{m}$ (25), $0.5 \mu \mathrm{m}(26,27)$.
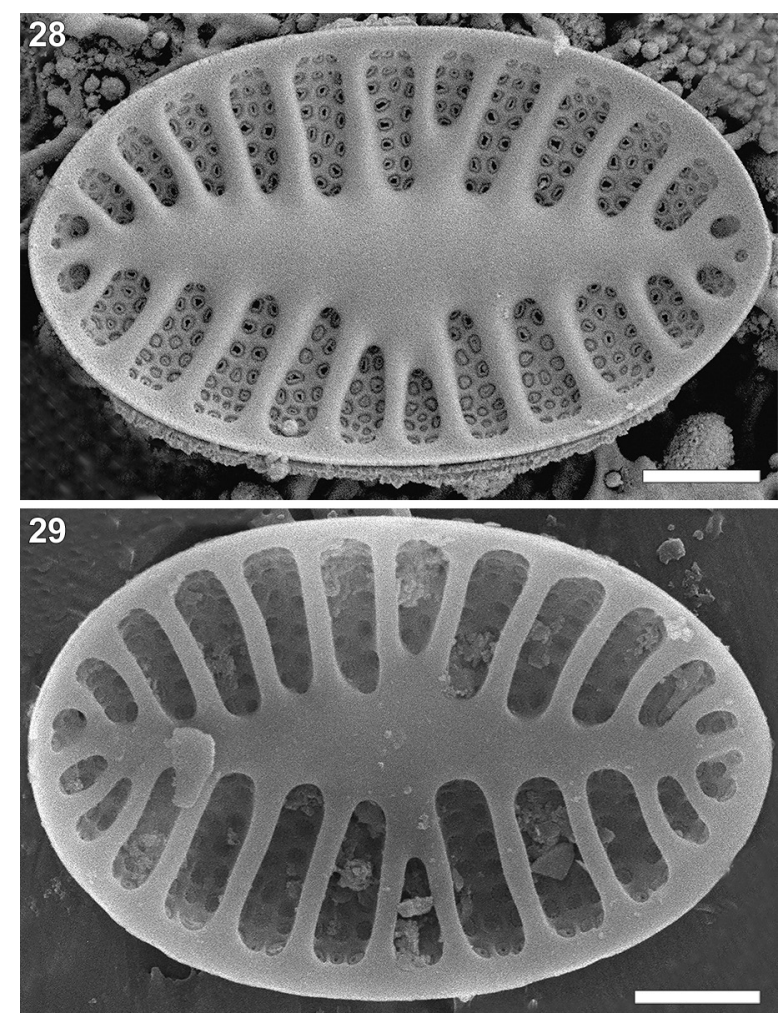

Figs 28-29. Platebaikalia elegans comb. nov. SEM, rapheless valves, internal views: $(28,29)$ whole valve. Scale bars $2.5 \mu \mathrm{m}(28), 2$ $\mu \mathrm{m}(29)$. this genus easily from Platebaikalia gen. nov.

Morphology of striae is also a distinguishing feature between Platebaikalia elegans comb. nov. and the genus Platessa, as that genus was originally described. Our morphological and molecular investigation of monoraphid diatoms shows that the type of striae that is uniseriate, biseriate or multiseriate striation, are constant taxonomical features at the level of genus (KULIKOVSKIY et al. 2016, 2019). However, the genus Platessa is not unified in this regard, suggesting the genus may not be monophyletic. Of course, either a formal analysis of morphology and/or molecular investigations will be important to test that in the future.

An review of the 28 known species of the genus Platessa allows us to divide them to 8 groups, which we characterize below:

The first group has species with biseriate striae on both valves, and includes the type species of the genus. This group includes $P$. stewartia, $P$. guianensis, $P$. itoupensis, $P$. brevicostata, $P$. bavarica, $P$. holsatica, $P$. conspicua, P. ziegleri, P. hustedtii, P. baicalofontelli, $P$. undulans. Almost all species of this group share similar morphology. Platessa itoupensis is characterized by biseriate striae with some multiseriate striae with three rows of areolae. However, this third row of areolae is small and this species does not exhibit the tendency to multiseriate striae like as seen in Planothidium or in Platebaikalia gen. nov.

The second group includes a taxon with biseriate stria on both valves, but differs from the generitype and its allies by having a sinus on the rapheless valve. This is seen in P. strelnikovae and is not typical for Platessa (Krammer \& LANGe-Bertalot 2004; Enache et al. 2014). Also, the sinus divides striation on one side valve (ENACHE et al. 2014). Presence of sinus or cavum in Planothidium is an important feature for delimitation of two groups of taxa, a result that is supported by molecular evidence (see JAHN et al. 2017 and discussion below).

A third group of Platessa species includes taxa with the raphe valve having uniseriate striae and the rapheless valve having biseriate striae with a tendency to having three rows of areolae (multiseriate striae). This group includes two species, $P$. kingstonii and $P$. lutheri. The first species was studied by Potapova (2012) from North America. This species is characterized by uniseriate striae on raphe valve with a bow-tie shaped central area that is not typical for Platessa. The second species was also investigated by PoтAPOVA (2012) who demonstrated that this species has a stronger tendency to having three rows of areolae comprising the striae on rapheless valves. At the same time, $P$. lutherii is similar to $P$. kingstonii in having a bow-tie shaped central area and more elevated and massive interstriae than the generitype of Platessa.

A fourth group of Platessa species includes those species with uniseriate striae on both valves. Three species are possible to include to this group. These are P. guangzhouae, $P$. cataractarum and $P$. uniseriata. The first species was described from China (LiU et al. 2014). This species is 
characterized by the presence of a bow-tie shaped central area that is more typical for Psammothidium but not for Platessa. Presence of a hyaline area between valve face and mantle is also a feature known in Psammothidium (BukhtiYARova \& Round 1996; Monnier et al. 2007). In the generitype of Platessa, striae extend onto the mantle without a hyaline area. The presence of external distal raphe ends on valve face is also of interest in this taxon. BuKHTIYARova \& Round (1996) discussed the distal raphe ends seen in $P$. guangzhouae to be typical for Psammothidium as "type (1) drop-type at last stria". Additionally, this species is characterized by elevated, massive and broad interstriae alternating with striae on the rapheless valve. In Platessa interstriae are flat and mainly of equal width as the striae but not as broad as in Psammothidium. We conclude that after considering the suite of morphological features of $P$. guangzhouae that it belongs to the genus Psammothidium. P. cataractarum was investigated in detail by TUDESQUE et al. (2016). This species is characterized by uniseriate striae with a tendency to biseriate in some striae. However, this species cannot be described as having biseriate striae. All morphological features of $P$. cataractarum, including the presence of an hyaline area between valve face and mantle, raphe morphology and interstriae morphology are similar to what is seen in $P$. guangzhouae and with the genus Psammothidium. We also suggest the transfer of
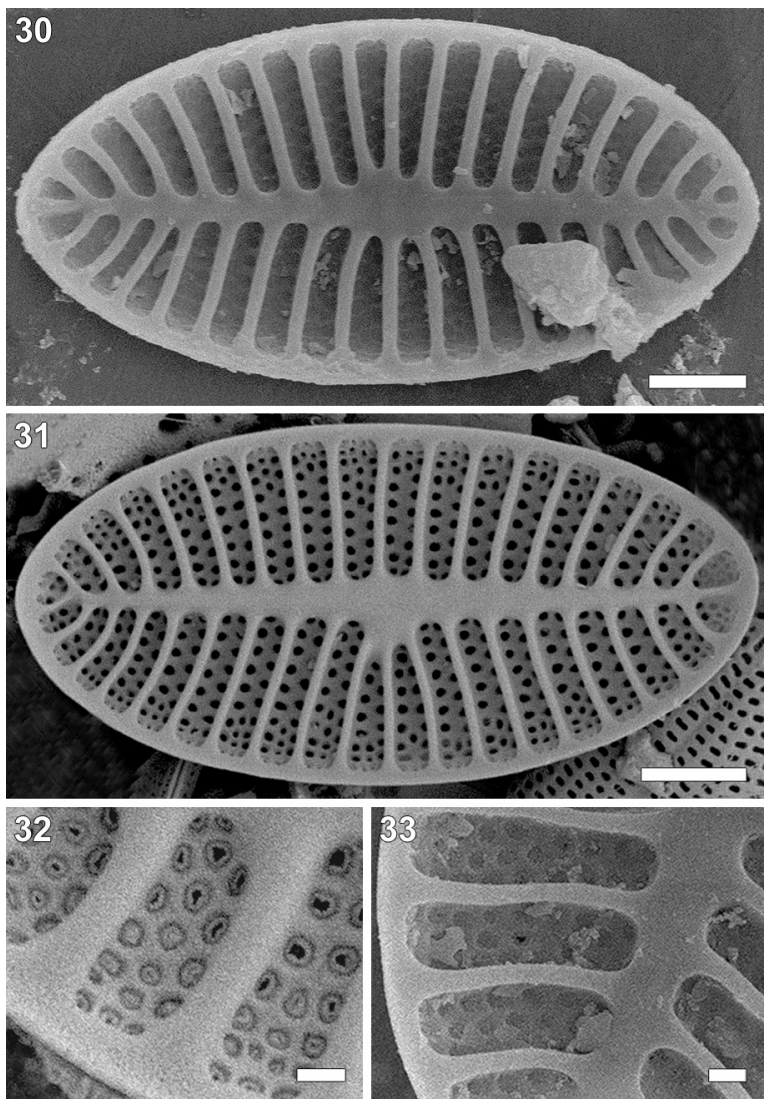

Figs 30-33. Platebaikalia elegans comb. nov. SEM, rapheless valves, internal views: $(30,31)$ whole valve; $(32,33)$ striae. Scale bars $3 \mu \mathrm{m}(31), 2.5 \mu \mathrm{m}(30), 0.5 \mu \mathrm{m}(32,33)$.
P. cataractarum to Psammothidium. Platessa uniseriata was studied in detail by MonNIER et al. (2003) from a freshwater tropical aquarium in France. All morphological features present in the two previously-discussed species are also present in P. uniseriata, except for the tie-bow shaped central area (MonNIER et al. (2003). The central area of $P$. uniseriata is more elliptical, a feature that is typical for Psammothidium but not for Platessa. So, we also suggest to transfer this species to the genus Psammothidium.

A fifth group of Platessa species includes the very interesting species $P$. joursacense which, like the previous group, has uniseriate striae in both valves. However, in this species the rapheless valves possess a cavum (see CHUdAEV et al. 2015). Presence of cavum in this species, like the sinus in the previously-mentioned $P$. strelnikovae demonstrates that these morphological features arose many times in different lineage of monoraphid diatoms. Presence of sinus or cavum is important feature for delimitation of two independent groups in the genus Planothidium (JAHN et al. 2017). In many cases a sinus or cavum is present in rapheless valves only, but in the genus Gliwiczia Kulikovskiy, Lange-Bertalot \& Witkowski a cavum is present on both valves (KULIKOVSKIY et al. 2013).

The sixth group includes $P$. bahlsii, a species that is characterized by having multiseriate striae on both valves (Potapova 2012). This species is easily distinguished from other Platessa taxa by having multiseriate striae in both valves. The morphology of the striae is typical for the genus Planothidium. They have 3-4 rows of areolae. Interstriae are narrower than the striae, and the valve face is flat. Distal raphe ends are slightly extend onto the mantle and curve in the same direction (see PoTAPOVA 2012: fig. 85). They are not linear and straight at the level of last distal stria as is seen in Platessa. External proximal raphe ends are curved in the same direction and opposite that of the curvature of the external distal raphe ends. This organization of the raphe ends is typical for Planothidium (Round \& BukHTIYAROVA 1996; VAN DE ViJVER et al. 2013; Wetzel et al. 2019). Internally, the raphe is situated in a raised sternum and striae are situated in depressions between interstriae. Distal and proximal raphe ends are curved to different sides and opposite each other. All these features are typical for the genus Planothidium but not for Platessa (see Supplementary table). We believe that all morphological features suggest that $P$. bahlsii belongs to the group of species without sinus or cavum in the genus Planothidium (WeTzEL et al. 2019), requiring a new nomenclatural combination for this taxon.

A seventh group of Platessa species includes those species with biseriate striae on the raphe valve and uniseriate striae in rapheless valves. Two species are referred to this group. These species were described from Lake Baikal, P. baicalensis and P. rhombicolanceolata (KULIKOVSKIY et al. 2015). KULIKOVsKIY et al. (2015) presented one SEM picture of the exterior of the 
Table 1. Platessa species and the morphological groups in which they are placed.

\begin{tabular}{|c|c|}
\hline Species & $\begin{array}{l}\text { Group within } \\
\text { Platessa }\end{array}$ \\
\hline \multicolumn{2}{|l|}{ Species originally placed in the genus } \\
\hline Platessa bavarica Lange-Bertalot et Hofmann (KRAMMER \& LANGE-BerTALOT 2004) & 1 \\
\hline Platessa brevicostata (Hustedt) Lange-Bertalot (KRAMMER \& LANGE-BERTALOT 2004) & 1 \\
\hline Platessa cataractum (Hustedt) Lange-Bertalot (KRAMMER \& LANGE-BerTALOT 2004) & $\begin{array}{l}\text { 4; transferred to } \\
\text { Psammothidium }\end{array}$ \\
\hline Platessa conspicua (Ant. Mayer) Lange-Bertalot (LANGE-Bertalot 2004) & 1 \\
\hline Platessa holsatica (Hustedt) Lange-Bertalot (Krammer \& LANGE-Bertalot 2004) & 1 \\
\hline Platessa hustedtii (Krasske) Lange-Bertalot (LANGE-Bertalot 2004) & 1 \\
\hline Platessa montana (Krasske) Lange-Bertalot (KrAMmer \& LANGE-BerTALOT 2004) & 8 \\
\hline Platessa obscura (Krasske) Lange-Bertalot (KrAmMER \& LANGE-BerTALOT 2004) & 8 \\
\hline Platessa rupestris (Krasske) Lange-Bertalot (LANGE-BerTALOT 2004) & 8 \\
\hline Platessa ziegleri (Lange-Bertalot) Lange-Bertalot (Krammer \& LANGE-Bertalot 2004) & 1 \\
\hline \multicolumn{2}{|l|}{ Species subsequently placed in the genus } \\
\hline Platessa bahlsii Potapova (РотAPova 2012) & $\begin{array}{l}\text { 6; transferred to } \\
\text { Planothidium }\end{array}$ \\
\hline Platessa baicalensis Kulikovskiy et Lange-Bertalot (KuLIKovsKIY et al. 2015) & 7 \\
\hline Platessa baicalofontellii Kulikovskiy et Lange-Bertalot (KULIKOvSKIY et al. 2015) & 1 \\
\hline Platessa elegans Kulikovskiy et Lange-Bertalot (KuLIKOvsKIY et al. 2015) & $\begin{array}{l}\text { new genus Plate- } \\
\quad \text { baicalia }\end{array}$ \\
\hline Platessa fontellii (Cleve-Euler) Lange-Bertalot et Kulikovskiy (KuLIKovskiY et al. 2015) & 8 \\
\hline Platessa guangzhouae Liu et Kociolek (LiU \& KocıoleK 2014) & $\begin{array}{l}\text { 4; transferred to } \\
\text { Psammothidium }\end{array}$ \\
\hline Platessa guianensis Le Cohu, Tudesque et C.E. Wetzel (Le CoHU et al. 2016) & 1 \\
\hline Platessa itoupensis Tudesque, Le Cohu et C.E. Wetzel (TudesQue et al. 2016) & 1 \\
\hline Platessa kingstonii Potapova (PоTAPOva 2012) & 3 \\
\hline Platessa krejcii (Hustedt) C.E. Wetzel, Tudesque et Le Cohu (Wetzel et al.2016) & 8 \\
\hline Platessa lutheri (Hustedt) Potapova (PотAPova 2012) & 3 \\
\hline Platessa rhombicolanceolata Kulikovskiy et Lange-Bertalot (KuLIKovsKiY et al. 2015) & 7 \\
\hline Platessa stewartii (Patrick) Potapova (PотAPOva 2012) & 1 \\
\hline Platessa strelnikovae Enache, Potapova et Morales (ENACHE et al. 2014) & 2 \\
\hline Platessa tropica (Hustedt) C.E. Wetzel, Tudesque et Le Cohu (WeTzel et al. 2016) & 8 \\
\hline Platessa undulans Kulikovskiy et Lange-Bertalot (KuLIKOvsKIY et al. 2015) & 1 \\
\hline $\begin{array}{l}\text { Platessa uniseriata (Lange-Bertalot et Monnier) C.E. Wetzel, Tudesque et Le Cohu (Wetzel } \\
\text { et al. 2016) }\end{array}$ & $\begin{array}{l}\text { 4; transferred to } \\
\text { Psammothidium }\end{array}$ \\
\hline Platessa joursacense (Héribaud) Chudaev (CHUDAEv 2015) & 6 \\
\hline
\end{tabular}

raphe valve of $P$. baicalensis. Additional morphological investigations will be important to show morphological differences with genus Platessa sensu stricto. Our new data (Kulikovskiy unpubl. data) show that these two species have differences as compared to the generitype of Platessa and as may require an independent genus to accommodate them.

A group of species requiring further investigation 
are put together in the eighth and final group. These include $P$. krejcii, $P$. tropica, $P$. fontellii, $P$. montana, $P$. obscura and $P$. rupestris. Additional scanning electron microscope investigations of these poorly-studied taxa are necessary to further document them and assess even greater morphological variation among taxa currently included in the genus Platessa.

Our investigation of species from the genus Platessa, assigning them to eight different groups based on morphology, as well as the description of the new genus Platebaikalia, suggest the possibility that Platessa is catch-all genus. We can compare this situation with Navicula previously when many different taxa at the level of genus were combined together on the basis of naviculoid symmetry (KULIKOVSKIY et al. 2019). Lange-Bertalot (in KrAMMER \& LANGE-BERTALOT 2004) described the genus Platessa on the basis of a combination of morphological features unknown in other described monoraphid genera at that time. However, progress in morphological and taxonomical investigations, including the description of many new taxa, especially from poorly-studied Lake Baikal, has shown that no "intermediate species" sensu Potapova (2012) exist between some closely-related genera, but instead we have a large diversity of monoraphid diatoms whose taxonomy must be addressed within a modern taxonomic framework. A good example of this situation in some closely-related taxa is the criticism of the description of the genus Psammothidium and its circumscription relative to Achnanthidium on the basis morphological investigation (see Monnier et al. 2007). However, molecular studies of these two genera (albeit with limited taxon sampling relative to the size of Achnanthidium) show that they are independent taxa (KULIKOVSKIY et al. 2016). So, a combination of morphological features like valve shape, raphe morphology, shape of central area, stria structure and others, can play an important role in the diagnosis and evolution of monoraphid taxa.

\section{New combinations:}

Platebaikalia elegans (Kulikovskiy et Lange-Bertalot) Kulikovskiy, Glushchenko, Genkal et Kociolek comb. nov.

Basionym: Platessa elegans KuLIKovSKIY \& LANGE-BerTALOT 2015. Lake Baikal: Hotspot of endemic diatoms II. Iconographia Diatomologica. V. 26. P. 66-67. Figs 76: 1-16, 77: 1, 2.

Psammothidium guangzhouae (Y. Liu et J.P. Kociolek) Kulikovskiy, Glushchenko et Kociolek comb. nov. Basionym: Platessa guangzhouae Y. Liu et Kociolek in Y. LiU, J.P. Kociolek, Q. Wang, X. Tan \& Y. Fan 2014, Phytotaxa 188, p. 34; figs 7-16, 23-26.

Psammothidium cataractarum (Hustedt) Kulikovskiy, Glushchenko et Kociolek comb. nov.

Basionym: Cocconeis cataractarum HusTEDT 1937, Archiv für Hydrobiologie, Supplement 15, p. 189; pl. XIII, figs 10-14.

Psammothidium uniseriataum (Lange-Bertalot et
Monnier) Kulikovskiy, Glushchenko et Kociolek comb. nov., stat. nov.

Basionym: Achnanthes rupestoides var. uniseriata Lange-Bertalot et Monnier in Monnier, LANGe-Bertalot \& Bertrand 2003, Bulletin de la Société des Sciences Naturelles de l'Ouest de la France (Nantes), p. 134; figs 29-34.

Planothidium bahlsii (Potapova) Kulikovskiy, Glushchenko \& Kociolek comb. nov.

Basionym: Platessa bahlsii PотAPOva 2012, Diatom Research 27, p. 38; figs 84-96.

ACKNOWLEDGEMENTS

The study was supported by grants of the Russian Science Foundation (№19-14-00320).

\section{REFERENCES}

Bukhtiyarova, L. \& Round, F.E. (1996): Revision of the genus Achnanthes sensu lato. Psammothidium, a new genus based on Achnanthidium marginulatum. - Diatom Research 11: 1-30.

Chudaev, D.A.; Gololobova, M.A. \& Kulikovskiy, M.S. (2015): On taxonomic position of two species of achnanthoid diatoms (Achnanthidiaceae, Bacillariophyceae). - Nov. Sist. Nizsch. Rast. 49: 110-116.

Cox, E.J. (2015): Coscinodiscophyceae, Mediophyceae, Fragilariophyceae, Bacillariophyceae (Diatoms). - In: JAKLITSCH, W.; BARAL, H.O.; LÜCKING, R.; LUMBSCH, H.T. \& Frey, W. (eds): Syllabus of Plant Families. Adolf Engler's Syllabus der Pflanzenfamilien. Part 2/1. Photoautotrophic eukaryotic Algae: Glaucocystophyta, Cryptophyta, Dinophyta/Dinozoa, Haptophyta, Heterokontophyta/ Ochrophyta, Chlorarachniophyta/Cercozoa, Euglenophyta/ Euglenozoa, Chlorophyta, Streptophyta. - pp. 64-103, Borntraeger Verlagsbuchhandlung, Stuttgart.

Davidovich, N.A.; Davidovich, O.I.; WitKowsKi, A.; Li, C.; DABEK, P.; MANN, D.G.; ZGlOBICKA, I.; KURZYDlOWSKI, K.J.; Gusev, E.S.; GóreckA, E. \& Krzywda, M. (2017): Sexual reproduction in Schizostauron (Bacillariophyta) and a preliminary phylogeny of the genus. - Phycologia 56: 77-93.

Enache, M.D. \& Potapova, M.G. (2012): A new species of Eucocconeis (Bacillariophyceae) from North America. - Diatom Research 27: 75-80.

Jahn, R.; Abarca, N.; Gemeinholzer, B.; Mora, D.; Skibbe, O.; Kulikovskiy, M.; Gusev, E.; Kusber, W.-H. \& ZimmermanN, J. (2017): Planothidium lanceolatum and Planothidium frequentissimum reinvestigated with molecular methods and morphology: four new species and the taxonomic importance of the sinus and cavum. - Diatom Research 32: 75-107.

JASNITSKY, V.N. (1936): Neue und interessante Arten der Diatomeen aus dem Baikalsee. - Journal Botanique de l'URSS 21: 689-703.

JASNITSKY, V.N. (1952): Gigantism in Lake Baikal flora. Proceedings of biological-geographical Institute of Irkutsk University 13: 3-11.

Krammer, K. \& LANGE-Bertalot, H. (2004): Bacillariophyceae 4. Teil: Achnanthaceae, Kritische Erganzungen zu Navicula (Lineolatae), Gomphonema Gesamtliteraturverzeichnis Teil 1-4 (second revised edition). - In: ETTL, H. et al. (eds): Sußwasserflora von Mitteleuropa, vol. 2(4). - pp. 
1-468, Spektrum Akademischer Verlag, Heidelberg.

Kociolek, J.P.; Balasubramanian, K.; Blanco, S.; Coste, M.; ECTOR, L.; LIU, Y.; KULIKOVSKIY, M.; LUNDHOLM, N.; Ludwig, T.; Potapova, M.; Rimet, F.; SabBe, K.; Sala, S.; SAR, E.; TAYlor, J.; VAN DE ViJVer, B.; WetZel, C.E.; Williams, D.M.; Witkowski, A. \& Witkowski, J. (2019): DiatomBase. Platessa H. Lange-Bertalot, 2004. Accessed at: http://www.diatombase.org/aphia. php? $\mathrm{p}=$ taxdetails\&id $=603212$ on 2019-09-09

Kulikovskiy, M.S.; GlushchenKo, A.M.; KuZnetsova, I.V. \& GENKAL, S.I. (2016): Identification book of diatoms from Russia. - pp. 1-804, Filigran, Yaroslavl. (In Russ.).

Kulikovskiy, M.S.; Lange-Bertalot, H. \& KuZnetsova, I.V. (2015): Lake Baikal: hotspot of endemic diatoms II. - Iconographia Diatomologica 26: 1-657.

Kulikovskiy, M.S.; LANGe-Bertalot, H.; Metzeltin, D. \& WitKowski, A. (2012): Lake Baikal: hotspot of endemic diatoms. I. - Iconographia Diatomologica 23: 7-608.

Kulikovskiy, M.S.; LANGe-Bertalot, H. \& A. WitkowsKi (2009): Nupela matrioschka sp. nov., Nupela thurstonensis comb. nov. and Nupela neogracillima comb. \& nom. nov. (Bacillariophyceae): critical analysis of their morphology. - Polish Botanical Journal 54: 13-20.

Kulikovskiy, M.S.; LANGe-Bertalot, H. \& WitKowski, A. (2013): Gliwiczia gen. nov. a new monoraphid diatom genus from Lake Baikal with a description of four species new for science. - Phytotaxa 109: 1-16.

Kulikovskiy, M.S.; LANGe-Bertalot, H.; Witkowski, A. \& KhuRSEVICH, G.K. (2011): Achnanthidium sibiricum (Bacillariophyceae), a new species from bottom sediments in Lake Baikal. - Algological Studies 136/137: 77-87.

Kulikovskiy, M.S.; Maltsev, Ye.I.; Andreeva, S.A.; GlushchenKo, A.M.; Gusev, E.S.; PodunaY, Yu.A.; Ludwig, T.V.; Tusset, E. \& KocioleK, J.P. (2019): Description of a new diatom genus Dorofeyukea gen. nov. with remarks on phylogeny of the family Stauroneidaceae. - Journal of Phycology 55: 173-185.

LANGE-Bertalot, H. \& Krammer, K. (1989): Achnanthes, eine Monographie der Gattung mit Definition der Gattung Cocconeis und Nachträgen zu den Naviculaceae. Bibliotheca Diatomologica 18: 1-393.

LANGe-Bertalot, H. \& Ruppel, M. (1980): Zur Revision taxonomisch problematischer, ökologisch jedoch wichtiger Sippen der Gattung Achnanthes Bory. - Algological Studies 26: 1-31.

LiU, Y.; KocioleK, J.P.; Wang, Q. \& FAN, Y. (2014): Two new species of monoraphid diatom (Bacillariophyceae) from South of China. - Phytotaxa 188: 31-37.

ManN, D.G. (1981): Sieves and flaps: siliceous minutiae in the pores of raphid diatoms. - In Ross, R. (ed.): Proceedings of the 6th Symposium on Recent and Fossil Diatoms. - pp. 279-300, Otto Koeltz, Koenigstein.

Monnier, O.; Lange-Bertalot, H.; Hoffmann, L. \& Ector, L. (2007): The genera Achnanthidium Kützing and Psammothidium Bukhtiyarova et Round in the family Achnanthidiaceae (Bacillariophyceae): a reappraisal of the differential criteria. - Cryptogamie, Algologie 28: 141-158.

Nakov, T.; Beaulieu, J.M. \& Alverson, A.J. (2019): Accelerated diversification is related to life history and locomotion in a hyperdiverse lineage of microbial eukaryotes (Diatoms, Bacillariophyta). - New Phytologist 219: 462-473.

Novais, M.H.; JÜTTNER, I.; VAN DE VIJVER, B.; MoraIs, M.M.; HofFManN, L. \& ECtor, L. (2015): Morphological variability within the Achnanthidium minutissimum species complex (Bacillariophyta): comparison between the type material of Achnanthes minutissima and related taxa, and new freshwater Achnnathidium species from Portugal. - Phytotaxa 224: 101-139.

Potapova, M.G. (2012): New species and combinations in monoraphid diatoms (family Achnanthidiaceae) from North America. - Diatom Research 27: 29-42.

Potapova, M. \& Hamilton, P.B. (2007): Morphological and ecological variation within the Achnanthidium minutissimum (Bacillariophyceae) species complex. - Journal of Phycology 43: 561-575.

Romero, O.E. (2016): Study of the type material of two Platessa Lange-Bertalot species, formerly Cocconeis brevicostata Hust. and Cocconeis cataractarum Hust. (Bacillariophyta). - Diatom Research 31: 63-75.

Round, F.E \& BASson, P.W. (1997): A new monoraphid diatom genus (Pogoneis) from Bahrain and the transfer of previously described species $A$. hungarica and $A$. taeniata to new genera. - Diatom Research 12: 71-81.

Round, F.E. \& BukhtiYarova, L. (1996): Four new genera based on Achnanthes (Achnanthidium) together with a re-definition of Achnanthidium. - Diatom Research 11: 345-361.

Round, F.E.; Crawford, R.M. \& Mann, D.G. (1990): The Diatoms. Biology and morphology of the genera. pp. 1-747, Cambridge University Press, Cambridge.

Shi, Y.; Wang, P.; Kim, H.-K.; Lee, H.; Han, M.-S. \& Kim, B.-H. (2018): Lemnicola hungarica (Bacillariophyceae) and the new monoraphid diatom Lemnicola uniseriata $\mathrm{sp}$. nov. (Bacillariophyceae) from South Korea. - Diatom Research 33: 69-87.

SKABICHEVSKY, A.P. (1936): New and interesting diatoms from Northern Baikal. - Botanical Journal of USSR 21: 706-722.

SkABICHEvSKY, A.P. (1952): On the taxonomy of the Lake Baikal diatoms. - Notulae systematicae Academiae scientarum URSS, Instituti Botanici, Sectione Cryptogamica 8: $36-42$.

Skabichevsky, A.P. (1975): New species of diatomeae from overgrowths of the Baikal sublitooral. - Ukrainian Botanical Journal 32: 268-271.

Skabichevsky, A.P. (1984): Species Gomphonematis Ag. (Bacillariophyta) Lacus Baical. - News of the systematics of lower plants 21: 51-62.

Skabichevsky, A.P. (1985): About two species of Gomphonema Ag. (Bacillariophyta) from Lake Baikal. - Bulletin of Moscow Society of Naturalists. Biological Series 90: 92-103.

SKABICHEVSKY, A.P. (1987): Materies ad floram Bacillariophytprum zonae sublitoralis Lacus Baical. - News of the systematics of lower plants 24: 72-79.

Skvortzow, B.W. (1937): Bottom diatoms from Olhon gate of Baikal Lake, Siberia. - The Philippine Journal of Science 62: 293-377.

Skvortzow, B.W. \& Meyer, C.I. (1928): A contribution to the diatoms of Baikal Lake. - Proceedings of the Sungaree River Biological Station 1: 1-55.

Tudesque, L.; Cohu, R.L. \& Wetzel, C.E. (2016): Two new Platessa (Bacillariophyceae) from Amazonia: Platessa guianensis spec. nov., and P. itoupensis spec. nov. Phytotaxa 267: 237-255.

Van de ViJver, B.; Wetzel, C.E.; Kopalova, K.; Zidarova, R. \& ECTOR, L. (2013): Analysis of the type material of Achnanthidium lanceolatum Brébisson ex Kützing 
(Bacillariophyta) with the description of two new Planothidium species from the Antarctic Region. Fottea 13: 105-117.

Wetzel, C.E.; Van de Vijver, B.; Blanco, S. \& Ector, L. (2019): On some common and new cavum-bearing Planothidium (Bacillariophyta) species from freshwater. - Fottea 19: 50-89.

Supplementary material

the following supplementary material is available for this article:

Table S1. Comparison of different freshwater monoraphid diatom genera.

This material is available as part of the online article (http:// fottea.czechphycology.cz/contents)

(C) Czech Phycological Society (2020)

Received September 15, 2019

Accepted October 29, 2019 